\title{
Surgical outcome of orbital cavernous hemangioma: a case series
}

\author{
Nyoman Golden' \\ Tjokorda Gde Bagus \\ Mahadewa' \\ Christopher Ryalino² \\ 'Department of Neurosurgery, \\ School of Medicine, Udayana \\ University/Sanglah General Hospital, \\ Bali, Indonesia; ${ }^{2}$ Department of \\ Anesthesiology, School of Medicine, \\ Udayana University/Sanglah General \\ Hospital, Bali, Indonesia
}

This article was published in the following Dove Press journal: Open Access Surgery

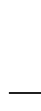

\begin{abstract}
The surgical outcome of orbital cavernous hemangiomas has been reported either by ophthalmologists, who preferred anterior approach, or by neurosurgeons, who favored transcranial approach. In this series, we reported the surgical outcome of ten patients with orbital cavernous hemangioma. The clinical findings varied from obvious axial proptosis in all patients (100\%), visual impairment (60\%), limited ocular movement $(50 \%)$, and orbital pain $(60 \%)$. The surgical outcomes were determined at their last follow-up and examination, where $80 \%$ of the cases had a good outcome, one patient had permanent visual damage and partial ptosis (poor), and another patient had an unchanged visual function (fair). Transcranial approach is still an appropriate surgical approach for most orbital cavernous hemangioma with good and acceptable surgical outcomes. Generally, lateral orbitotomy is indicated for a lesion located at the lateral compartment of the orbit that does not affect orbital apex.
\end{abstract}

Keywords: transcranial approach, orbitotomy, ptosis, permanent visual damage

\section{Introduction}

Cavernous hemangioma is an uncommon vascular malformation. A cavernous hemangioma in the orbital bone is considered a relatively common benign vascular growth, especially in the adult. ${ }^{1-4}$ However, orbital cavernous hemangioma is often included in the tumoral series of the orbit, due to their behavior and radiological characteristics, which is different from brain vascular malformation. ${ }^{1,3,5}$

The clinical course of the orbital cavernous hemangioma is slowly progressive. Consequently, the orbit and the globe will be able to accommodate the volume expansion of the slow-developing mass. This situation has created many asymptomatic cases. Many reports had suggested that only symptomatic patients were the candidate and indicated for surgical treatment, while the asymptomatic ones were followed up by periodical clinical examination and radiological evaluation. ${ }^{1,3,6}$

The choice of surgical approach is different between neurosurgeons and ophthalmologists. ${ }^{2}$ Ophthalmologists prefer anterior and lateral approaches, while most neurosurgeons prefer transcranial approach. However, the surgical outcome between these approaches varied. ${ }^{1,2,4,7}$

We are reporting the surgical outcome of ten patients with orbital cavernous hemangioma treated over a period of 8 years. Nine patients underwent the transcranial approach surgery, and one patient underwent the lateral approach surgery.

All subjects in this study have provided written informed consent to be included in this report and to have their computed tomography (CT) scan result shared. The

Correspondence: Tjokorda Gde Bagus Mahadewa

Department of Neurosurgery, Udayana University/Sanglah General Hospital, Jl.

Kesehatan No. I, Bali 80I I4, Indonesia

Email tjokmahadewa@hotmail.com
Open Access Surgery 2019:12 I-5

Dovepress $f$ in $\Delta$ (c) (i) (5) 2019 Golden et al. This work is published and licensed by Dove Medical Press Limited. The full terms of this license are available at https://www.dovepress.com/terms. (c) you hereby accept the Terms. Non-commercial uses of the work are permitted without any further permission from Dove Medical Press Limited, provided the work is properly attributed. For
permission for commercial use of this work, please see paragraphs 4.2 and 5 of our Terms (https://www.dovepress.com/terms.php). 
reporting was reviewed and approved by the Committee of Ethical Research of Udayana University.

\section{Case presentation}

This is a serial case report of ten patients, in the age range of $28-50$ years. All patients originally came as outpatients to the Ophthalmology Clinic due to a slowly progressing proptosis before they were sent to the Neurosurgery Department. The beginning of the symptoms varied from 1 to 4 years before hospital admission. Original symptoms included axial proptosis in all patients (100\%), visual impairment (60\%), and orbital pain $(60 \%)$. The symptoms were progressing slowly and consistently. Seven patients had orbital cavernous hemangioma on the right eye, and three patients on the left eye.

Limited ocular movement was observed in five patients, and six patients had a visual impairment. Orbital CT scan showed a well-demarcated round lesion with the same density as brain tissue and a mass effect on muscular structure (Figure 1). Contrast enhancement was uniform. There were no intratumoral hemorrhages or calcification.

\section{Management and outcome}

Frontotemporal craniotomy with a semi bicoronal skin incision was performed in nine patients. The orbital roof was removed en bloc (orbitotomy) when possible, otherwise, we performed orbitectomy. A lateral orbitotomy was done in one patient. The lateral approach was performed through zygomaticofrontal orbitotomy by removing the lateral orbital wall. This approach was used for the lesion situated in the lateral part of the orbit without involving the orbital apex.

All patients had their lesions easily localized, and through the opening of the periorbital fascia and by retraction of the muscular group, the bluish red capsule of the lesion was easily recognized. Sometimes it was necessary to create a path between the muscle and fat tissue in medially located lesion. The optic nerve trunk was obvious among these tissues, and in all cases, it appeared to be completely intact and undamaged after tumor removal.

Of the ten lesions, nine were soft and easily separated by blunt dissection from the surrounding structures and one lesion was situated in the posteromedial of the orbit and

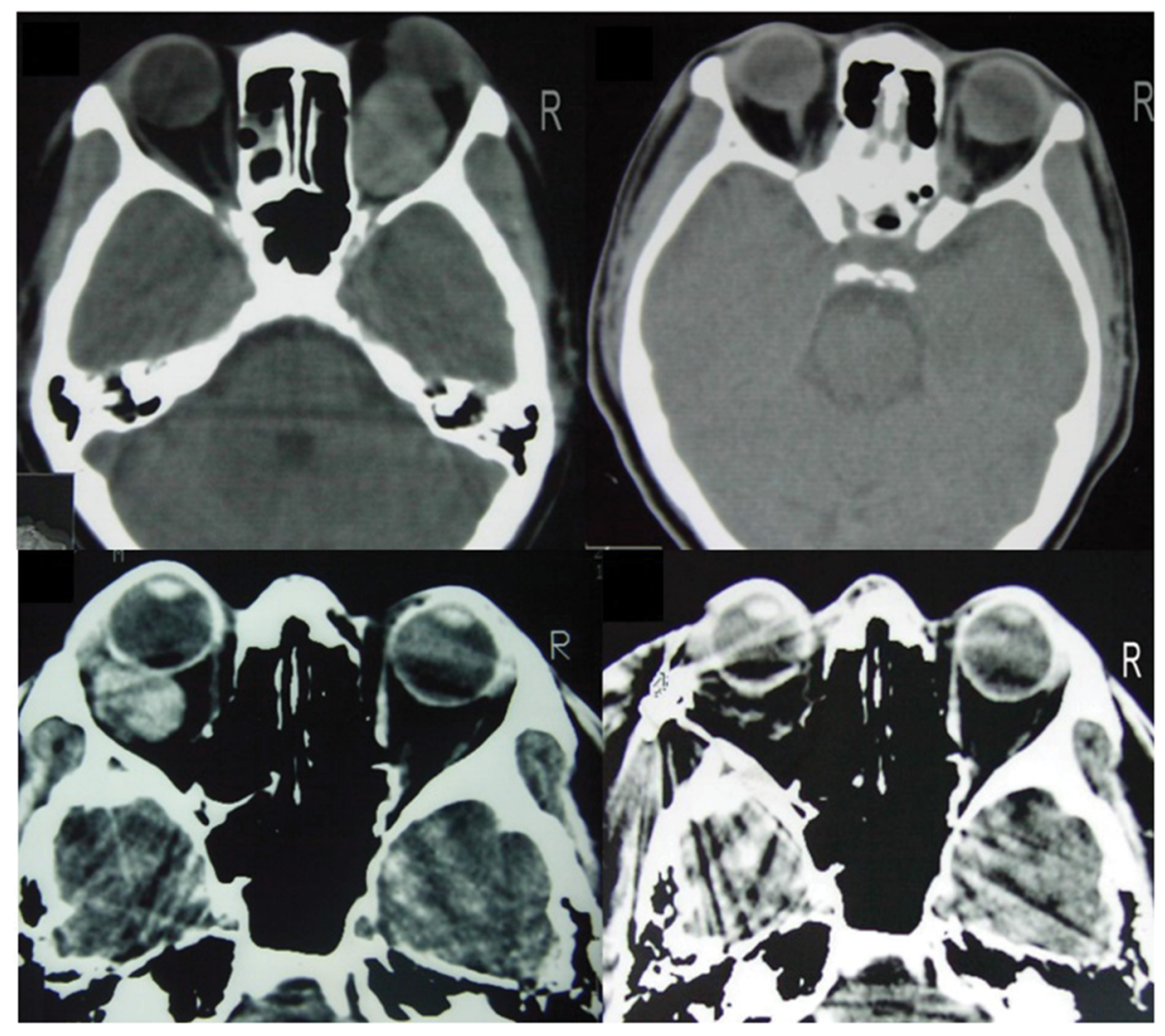

Figure I Some examples of orbital CT scans of our subjects showed a well-demarcated round lesion with same density as brain tissue and a mass effect on muscular structure.

Abbreviation: CT, computed tomography. 
extended to the orbital apex. It was hard and firmly adhered to the optic nerve sheath that needed a rather extensive manipulation to remove it en bloc. In this series, all lesions were located intraconally, well-encapsulated, and occurred as a single lesion. The average diameter of the lesions ranged between 2 and $3.5 \mathrm{~cm}$. The preoperative diagnosis of orbital cavernous hemangioma was confirmed by postoperative pathology examination in all cases.

Seven patients had a reduced proptosis immediately, and five patients had improved ocular mobility. Complications that occurred postoperatively were recovered in the majority of patients during follow-up (Table 1). Temporary ptosis occurred in two patients, but completely improved in one patient and partially in the other one. Postoperative ophthalmoplegia was discovered in two patients, and they recovered during their last follow-up. One patient had permanent visual deterioration after tumor removal, and one other patient had unchanged visual acuity. All ten patients were available for periodical follow-up and evaluation, and the time of followup ranged between 1 and 4 years.

Table I Surgical complications and results of patients in this series

\begin{tabular}{|l|l|l|}
\hline Complications & Early & At discharge \\
\hline Ophthalmoplegia & $2(20 \%)$ & 0 \\
Worsening visual acuity & $\mathrm{I}(10 \%)$ & $\mathrm{I}(10 \%)$ \\
Palpebral ptosis & $2(20 \%)$ & $\mathrm{I}(10 \%)$ \\
\hline
\end{tabular}

Definitive surgical outcomes were determined at the last examination (Table 2). Eight (80\%) patients were regarded as good, defined as the visual function and ocular movement was normal, no orbital pain, and the complete disappearance or significantly decreased proptosis. One (10\%) patient was considered fair, even though the visual function was unchanged or not improved, but the proptosis was significantly reduced. Poor outcome was observed in one $(10 \%)$ case with permanent visual acuity deterioration and irreversible ptosis. This last patient had a tumor located at the level of orbital apex which was difficult to remove. None had recurrent hemangioma during follow-up.

\section{Discussion}

Cavernous hemangioma is a low-flow vascular malformation. It consists of thrombosed and septated venous convolution, covered by compact and strong fibrous capsule..$^{1-3,7,8}$ It is commonly a benign vascular growth in the orbit, that mostly affected adult and more common in women. ${ }^{1,2,4,7}$ Orbital cavernous hemangioma grows faster in pregnant women and is thought to correlate to hormonal changes. ${ }^{9}$ The clinical course is slowly progressing without an intermittent period, and this slow growth makes the globe and orbit able to accommodate the volume expansion and developing mass, without producing disturbing symptoms. ${ }^{1,3}$ The common symptom is axial proptosis that occurred due to the location of the lesion which most commonly is within the intraconal space. ${ }^{1-3,7} \mathrm{In}$

Table 2 Clinical characteristics and surgical outcomes of the subjects reported

\begin{tabular}{|c|c|c|c|c|c|c|c|}
\hline $\begin{array}{l}\text { Case } \\
\text { number }\end{array}$ & Sex & $\begin{array}{l}\text { Age } \\
\text { (years) }\end{array}$ & $\begin{array}{l}\text { Symptoms } \\
\text { and signs }\end{array}$ & $\begin{array}{l}\text { Side of } \\
\text { tumor }\end{array}$ & Outcome & Results & $\begin{array}{l}\text { Follow-up } \\
\text { (years) }\end{array}$ \\
\hline 1 & $\mathrm{~F}$ & 50 & Proptosis, limited ocular movement & Right & $\begin{array}{l}\text { Improvement of proptosis, symptoms } \\
\text { free }\end{array}$ & Good & 4 \\
\hline 2 & M & 42 & Proptosis, hyperopia & Right & $\begin{array}{l}\text { Improvement of visual acuity and } \\
\text { proptosis, symptoms free }\end{array}$ & Good & 3 \\
\hline 3 & $\mathrm{~F}$ & 35 & Proptosis, hyperopia, orbital pain & Right & $\begin{array}{l}\text { Improvement of visual acuity and } \\
\text { proptosis, symptoms free }\end{array}$ & Good & 2 \\
\hline 4 & $\mathrm{~F}$ & 50 & $\begin{array}{l}\text { Proptosis, visual blurring, orbital } \\
\text { pain, limited ocular movement }\end{array}$ & Right & $\begin{array}{l}\text { Unchanged visual function, mild } \\
\text { proptosis }\end{array}$ & Fair & 2 \\
\hline 5 & $\mathrm{~F}$ & 35 & $\begin{array}{l}\text { Proptosis, visual blurring, limited } \\
\text { ocular movement, orbital pain }\end{array}$ & Right & $\begin{array}{l}\text { Mild proptosis, worsening of visual } \\
\text { acuity, ptosis }\end{array}$ & Poor & 2 \\
\hline 6 & $M$ & 32 & Proptosis, orbital pain & Left & $\begin{array}{l}\text { Improvement of proptosis, symptoms } \\
\text { free }\end{array}$ & Good & 2 \\
\hline 7 & $\mathrm{~F}$ & 42 & $\begin{array}{l}\text { Proptosis, limited ocular } \\
\text { movement, hyperopia }\end{array}$ & Right & $\begin{array}{l}\text { Improvement of visual acuity and } \\
\text { proptosis, symptoms free }\end{array}$ & Good & 2 \\
\hline 8 & M & 28 & Proptosis, orbital pain & Left & $\begin{array}{l}\text { Improvement of proptosis, symptoms } \\
\text { free }\end{array}$ & Good & 1.5 \\
\hline 9 & $\mathrm{~F}$ & 34 & $\begin{array}{l}\text { Proptosis, limited ocular } \\
\text { movement, hyperopia, }\end{array}$ & Right & $\begin{array}{l}\text { Improvement of visual acuity and } \\
\text { proptosis, symptoms free }\end{array}$ & Good & I \\
\hline 10 & $\mathrm{~F}$ & 37 & Proptosis, orbital pain. & Right & $\begin{array}{l}\text { Improvement of clinical picture and } \\
\text { symptoms free }\end{array}$ & Good & I \\
\hline
\end{tabular}


our cases, all patients showed obvious proptosis, a significant symptom that indicates surgical removal. Intralesional bleeding is extremely rare because of the strong fibrous capsule, which is different from brain cavernous hemangioma. There was no intratumoral bleeding in our series of cases. Orbital cavernous hemangioma is usually a single lesion. Multiple lesions are quite rare. ${ }^{1,2,7}$ In these case series, all patients had a single lesion.

CT scan was used preoperatively to diagnose orbital cavernous hemangioma. ${ }^{1-3}$ Studies had shown that preoperative CT scan had consistent findings to intraoperative or postoperative results. .,2,7,10 Orbital cavernous hemangioma appeared as an ovoid well-bordered lesion displacing muscular structures with the same density as cerebral parenchyma in CT scan. Contrast administration will show a homogeneous enhancement. ${ }^{1,2,11}$ The optic nerve and muscular structures could be delineated clearly on $\mathrm{CT}^{2}$ Cavernous hemangioma is an angiographically silent lesion, due to its small feeding artery and its slow flow circulation; therefore, angiography study is not necessary. $2,3,12$

Surgical resection of the lesion is always indicated in symptomatic patients, while asymptomatic patients should be clinically and radiologically followed up. The aim of surgical treatment is total removal of the lesion, while at the same time preserving the optic nerve and muscular structures as much as possible. ${ }^{1,2,7}$ Cavernous hemangioma is a well-known lesion by ophthalmologists, which favor anterior and lateral approach to excise the lesion. On the other hand, the neurosurgical practices prefer transcranial approach, especially when the lesions involve orbital apex.

En bloc removal is possible almost in all patients, and this is necessary to avoid bleeding in the surgical field. ${ }^{1,2} \mathrm{~A}$ good surgical view and exposure are important to see the anatomical relationship in a relatively small space. The use of optic magnification will give a better precision and identification of anatomical border of cavernous hemangioma and the surgical plane. ${ }^{2}$ En bloc removal provides less complication and ensures less recurrence. ${ }^{2}$

In our series, immediate surgical results were the reduction of proptosis and improvement of ocular movement. Ophthalmoplegia that occurred in two patients were improved several months postoperatively. The most devastating esthetic deficit was the permanent palpebral ptosis that affected one case, possibly due to the contusion of the elevator nerve of the eyelid. ${ }^{1,2}$ Missori et $\mathrm{al}^{2}$ reported $2(12 \%)$ cases who had permanent ptosis out of 25 cases. The dreadful complication of the surgical removal of orbital cavernous hemangioma is postoperative deterioration of visual function., ${ }^{2,7}$
There were some variations in regard to postoperative worsening of visual acuity, either by anterior or transcranial approaches. Cheng et $\mathrm{al}^{4}$ reported that by anterior (transconjunctival) approach, the postoperative visual impairment was around 5\%, while Harris and Jakobiec ${ }^{7}$ reported it as $24 \%$. As reported by Acciarri et $\mathrm{al}^{1}$, in the transcranial approach, there was 1 case out of 13 patients with orbital cavernous hemangioma who had postoperative visual impairment. In a bigger series of 48 patients with orbital cavernous hemangioma operated either by transcranial or anterior approaches, there was no visual damage reported. ${ }^{2}$ On the contrary, Missori et $\mathrm{al}^{2}$ reported that $8(32 \%)$ out of 25 patients had a postoperative visual impairment.

In general, the potential factor that resulted in postoperative visual impairment was the difficulty of the tumor removal, especially when the tumor was deep seated that caused "striae", disc swelling, envelopment/encasement of the optic nerve, or adhesion to the optic nerve, periosteum, or the muscles. The tumor located at the apex or medial of the optic nerve was very likely to be difficult to remove, and consequently would be followed by postoperative visual impairment. ${ }^{1,2}$

One of our case series had a postoperative visual impairment with tumor located at the apex. The manipulation during tumor excision might not directly damage the optic nerve, but it might damage the blood supply to the nerve. The blood vessels supplying the optic nerve were very tiny and difficult to identify during surgery, although the nerve itself was quite obvious. ${ }^{2}$ The damage to the blood vessels was followed by irreversible ischemia of the optic nerve. ${ }^{1.2}$ In our experience, we were sure that the difficulty in excising the tumor (in one case) was the important cause of postoperative visual impairment, and not caused by the particular surgical approach.

Cheng et $\mathrm{al}^{4}$ criticized the transcranial approach performed by Missori as the cause of postoperative visual impairment would be higher than the anterior/transconjunctival approach, but even though their postoperative visual impairment complication was small, their anterior approach was indicated only for medium-sized tumor and not located at the apex. Several studies reported that when there was no difficulty in removing the tumor, the visual impairment does not influence the visual outcome., ${ }^{2,6,13}$

Although the transcranial approach was thought to be too extensive and took longer surgical time, ${ }^{4,13}$ this approach had some advantages like it fits for different sizes of the tumor and it gave an ample surgical working space, that it would be easier to remove the tumor en bloc and to control surgi- 
cal bleeding. ${ }^{2}$ The clean and bloodless surgical field was important and needed for the topography of the tumor and surrounding anatomical hallmarks. The cosmetic result was good as the skin incision was hidden behind the hairline and the bone flap was fixed by titanium miniplate. Acciarri et $\mathrm{al}^{1}$ with 13 cases underwent this approach and reported that there was no cosmetic problem in their patients. We had nine cases who underwent transcranial approach, and none had a cosmetic problem as well. Generally, lateral orbitotomy is performed for a lesion in lateral orbit, which does not reach the apex,${ }^{14}$ and we had one case appropriate for this approach with good result.

\section{Conclusion}

Postoperative visual impairment was caused by potential difficulties in removing these tumors. When there was no difficulty in excising this tumor, the size of the lesion, preoperative visual impairment, and surgical approach do not influence the postoperative visual outcome.

Generally, lateral orbitotomy is indicated for a tumor located at the lateral part of the orbit that does not affect orbital apex. Our case series demonstrated that transcranial approach is still proper for almost all orbital cavernous hemangiomas with good surgical outcomes.

\section{Disclosure}

The authors report no conflicts of interest in this work.

\section{References}

1. Acciarri N, Giulioni M, Padovani R, Gaist G, Pozzati E, Acciarri R. Orbital cavernous angiomas: surgical experience on a series of 13 cases. J Neurosurg Sci. 1995;39(4):203-209.

2. Missori P, Tarantino R, Delfini R, Lunardi P, Cantore G. Surgical management of orbital cavernous angiomas: prognosis for visual function after removal. Neurosurgery. 1994;35(1):34-38.

3. Thorn-Kany M, Ph A, Delisle MB, Lacroix F, Lagarrigue J, Manelfe C. Orbital cavernous hemangiomas: MR imaging. J Neuroradiol. 1999;26:79-86.

4. Cheng JW, Wei RL, Cai JP, Li Y. Transconjunctival orbitotomy for orbital cavernous hemangiomas. Can J Ophthalmol. 2008;43(2):234-238.

5. Gonzalez LF, Lekovic GP, Eschbacher J, Coons S, Porter RW, Spetzler RF. Are cavernous sinus hemangiomas and cavernous malformations different entities? Neurosurg Focus. 2006;21(1):E6.

6. Kim YH, Baek SH, Choi WC. The transconjunctival approach to a large retrobulbar cavernous hemangioma of the orbit. Korean J Ophthalmol. 2002;16(1):37-42.

7. Harris GJ, Jakobiec FA. Cavernous hemangioma of the orbit. J Neurosurg. 1979;51(2):219-228.

8. Puca A, Colosimo C, Tirpakova B, Lauriola L, Di Rocco F. Cavernous hemangioma extending to extracranial, intracranial, and orbital regions. Case report. J Neurosurg. 2004;101(6):1057-1060.

9. Costa e Silva I, Symon L. Cavernous hemangioma of the optic canal. Report of two cases. J Neurosurg. 1984;60(4):838-841.

10. Yamasaki T, Handa H, Yamashita J, et al. Intracranial and orbital cavernous angiomas. J Neurosurg. 1986;10:197-208.

11. Savoiardo M, Strada L, Passerini A. Orbital cavernous hemangiomas: value of CT, angiography, and phlebography. AJNR Am J Neuroradiol. 1983;4:741-744.

12. del Curling O, Kelly DL, Elster AD, Craven TE. An analysis of the natural history of cavernous angiomas. J Neurosurg. 1991;75(5):702-708.

13. Hassler W, Schaller C, Farghaly F, Rohde V. Transconjunctival approach to a large cavernoma of the orbit. Neurosurgery. 1994;34(5):859-862.

14. Hajime A, Kiyoshi S, Toshiro K, Rhoton AL Jr. Lateral approach to intraorbital lesions: anatomic and surgical considerations. Surgical anatomy and technique. Neurosurgery. 1996;39:1157-1163.
Open Access Surgery

\section{Publish your work in this journal}

Open Access Surgery is an international, peer-reviewed, open access journal that focuses on all aspects of surgical procedures and interventions Patient care around the peri-operative period and patient outcomes pos surgery are key topics for the journal. All grades of surgery from minor cosmetic interventions to major surgical procedures are covered. Novel techniques and the

\section{Dovepress}

utilization of new instruments and materials, including implants and prostheses that optimize outcomes constitute major areas of interest. The manuscript management system is completely online and includes a very quick and fair peer-review system, which is all easy to use. Visit http://www.dovepress.com/ testimonials.php to read real quotes from published authors. 